УДК 376

DOI:

Людмила Мацук, кандидат педагогічних наук, доиент кафедри теорії та методики дошкільної і спеціальної освіти, ДВНЗ “Прикарпатський національний університет імені Василя Стефаника”" Олександра Кузенко, кандидат педагогічних наук, доиент кафедри украӥнознавства і філософії,

ДВНЗ “Івано-Франківський національний медичний університет”"

\title{
ПСИХОЛОГО-ПЕДАГОГІЧНІ ДОСЛІДЖЕННЯ АКТУАЛЬНИХ ПРОБЛЕМ ВПРОВАДЖЕННЯ ДОШКІЛЬНОЇ ІНКЛЮЗИВНОЇ ОСВІТИ В УКРАЇНІ
}

У статті окреслено психолого-педагогічні дослідження актуальних проблем впровадження дошкільної інклюзивної освіти в Україні. Зокрема, доведено, щуо досягнення позитивного результату інклюзивної освіти безпосередньо залежить від врахування в організації освітнього процесу психолого-педагогічних, соиіальних та фізіологічних потреб і можливостей дітей з особливими освітніми потребами. Розвиток означеної форми освіти дітей із особливими потребами в Україні зумовлює активізацію психолого-педагогічних досліджень украӥнськими ученими проблем організачії інклюзивного навчання, щуо сприяє ї̈ впровадженню в освітню практику.

Ключові слова: дошкільна освіта; освітнє середовище; інклюзивна освіта; інклюзивне навчання; діти з особливими освітніми потребами; порушення психофізичного розвитку.

תim. 20.

Lyudmyla Matsuk, Ph.D. (Pedagogy), Associate Professor of the Theory and Methods of Preschool and Special Education Department, State Higher Educational Institution Vasyl Stefanyk Precarpathian National University Oleksandra Kuzenko, Ph.D. (Pedagogy), Associate Professor of the Ukrainian Studies and Philosophy Department, State Higher Educational Institution "Ivano-Frankivsk National Medical University"

\section{PSYCHOLOGICALAND PEDAGOGICAL STUDY OF THE CURRENT PROBLEMS OF PRESCHOOL INCLUSIVE EDUCATION IMPLEMENTATION IN UKRAINE}

The article analyzes the modern psychological and pedagogical studies of the problem of pre-school inclusive education in Ukraine. The key issue is to ensure unlimited access to inclusive education for children with developmental disorders. Consideringing the problems of a pre-school inclusive education in Ukraine, it is noted that inclusive education is a pedagogical innovation, which is under implementation, and consequently has many difficulties in practice. First of all, this is the professional unpreparedness of preschool teachers of kindergarten to work with children with special educational needs, architectural unadaptability of premises, lack of additional financing of inclusive educational institutions, negative attitudes of parents of other children, etc. All these factors significantly complicate the process of implementation of inclusive education for preschoolers.

Stresses of the steady tendency of the birth rate of children with special educational needs in Ukraine and the introduction of inclusion into the educational process, objectively determines the need for psychological and pedagogical studies of the problem of reforming the traditional system of special education. Inclusive education in the scientific works of Ukrainian specialists in the field of special pedagogy is regarded as a system of educational services based on the principle of ensuring the right of children with disabilities to education in a general educational institution in his local residential area at the place of residence. This form of education excludes any discrimination, ensuring equality of all members of society, regardless of their nationality, gender, race, culture, social status, religion, individual abilities and skills.

Contemporary scholars consider inclusive learning to be such an educational environment that meets the needs and capabilities of each child, regardless of the characteristics of their psychophysical development. Inclusive education is a flexible, individualized system of education for children with special educational needs at the place of residence. The training takes place according to the individual curriculum and is provided by medical-social and psychological-pedagogical support.

Keywords: preschool education; an educational environment; inclusive education; children with special educational needs; psychophysical development disorders.

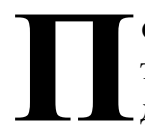

остановка проблеми. Стійка тенденція до зростання чисельності дітей $з$ особливими освітніми потребами в Україні та впровадження інклюзії в освітній процес об’єктивно зумовлює необхідність психолого-педагогічних досліджень проблеми реформування традиційної системи спеціальної освіти. Інклюзивна освіта в наукових працях 


\section{ПСИХОЛОГО-ПЕДАГОГІЧНІ ДОСЛІДЖЕННЯ АКТУАЛЬНИХ ПРОБЛЕМ ВПРОВАДЖЕННЯ ДОШКІЛЬНОЇ ІНКЛЮЗИВНОЇ ОСВІТИ В УКРАЇНІ}

українських фахівців у галузі спеціальної педагогіки розглядається як система освітніх послуг, що грунтується на принципі забезпечення права дітей із порушеннями психофізичного розвитку на освіту в умовах загальноосвітнього закладу за місцем проживання. Означена форма навчання виключає будь-яку дискримінацію, забезпечуючи рівноправність усіх членів суспільства, незалежно від їхньої національності, статі, раси, культури, соціального стану, релігії, індивідуальних можливостей і здібностей.

Досягнення позитивного результату інклюзивної освіти безпосередньо залежить від врахування в організації навчального процесу психолого-педагогічних, соціальних та фізіологічних потреб і можливостей дітей 3 особливими освітніми потребами. У широкому значенні до категорії дітей з особливими освітніми потребами належать ті учні (вихованці ЗДО), чиї освітні потреби виходять за межі загальноприйнятих освітніх норм і правил. Це належать як діти з особливостями психофізичного розвитку, так і обдаровані та діти із соціально вразливих груп. Кількісно найбільшою групою із цієї категорії в Україні є діти з особливостями (порушеннями) психофізичного розвитку. Стан їхнього здоров'я перешкоджає засвоєнню освітніх програм без створення спеціальних умов навчання через набуті чи вроджені, тимчасові або постійні відхилення у фізичному і (або) психічному розвитку.

Сучасні вчені розглядають інклюзивне навчання як створення освітнього середовища, яке відповідало б потребам і можливостям кожної дитини, незалежно від особливостей їі психофізичного розвитку. Інклюзивне навчання гнучка, індивідуалізована система навчання дітей 3 особливими освітніми потребами в умовах загальноосвітнього закладу за місцем проживання. Навчання відбувається за індивідуальним навчальним планом, забезпечується медикосоціальним та психолого-педагогічним супроводом.

Аргументуючи актуальність впровадження інклюзивної освіти, дослідники стверджують, що ця освітня модель зарекомендувала себе в усьому світі як дієва форма забезпечення освітніх потреб дітей із психофізичними порушеннями і узгоджується зі світовим загальним прагненням до соціальної справедливості (Slee R, 2001). Розвиток у сучасній Україні цієї форми освіти дітей із особливими потребами зумовлює активізацію психолого-педагогічних досліджень українськими ученими проблем організації інклюзивного навчання, що сприяє іiї впровадженню в освітню практику.
Аналіз актуальних досліджень. Проблему організації різних форм корекційно-розвивальної освіти в Україні досліджували вчені А. Колупаєва, I. Садова, Т. Сак, О. Таранченко; інтегрованого навчання та виховання дітей з особливостями психофізичного розвитку в загальноосвітніх закладах стала предметом грунтовного аналізу в українській психолого-педагогічній науці, що знайшловідображеннявпрацяхВ.Бондаря,А.Колупаєвої, С. Миронової, Г. Савіцької, Т. Сак, В. Синьова, Л. Будяк, В. Тарасун, В. Феоктісової, М. Шеремет, Д. Шульженко ін.; ідея забезпечення всебічного розвитку дітей в умовах сучасного закладу дошкільної освіти та необхідність широкої діагностики дошкільників стала предметом вивчення вченими А. Богуш, Н. Гавриш, T. Поніманської та ін. Більшість українських учених одностайні в твердженні, що інклюзивна освіта в широкому значенні - це гнучкіший підхід до навчання, унікальний процес доступної освіти для кожного, в якому відсутні бар'єри, пов'язані з відмінностями тих, хто навчається.

Мета статті - проаналізувати основні напрями психолого-педагогічних досліджень актуальних проблем впровадження дошкільної інклюзивної освіти в Україні.

Об'єкт дослідження - дошкільна інклюзивна освіта в Україні.

Виклад основного матеріалу. Ідея необхідності залучення дітей із психофізичними особливостями до навчального процесу разом із дітьми, розвиток яких відповідає віковій нормі набула широкого розповсюдження в зарубіжній психологопедагогічній теорії та практиці останніх десятиліть XX ст. Однак ще на початку XX ст. вітчизняний психолог Л. Виготський наголошував на доцільності створення системи навчання, в умовах якої дитина з обмеженими можливостями включається до колективу дітей 3 нормою вікового розвитку. Вчений зауважував, що ізоляція сліпого, глухого чи розумово відсталого вихованця у вузькому колі шкодить його розвитку, не дає можливості жити справжнім життям, не мотивує до самовдосконалення, не заохочує до спілкування, притупляє бажання творити.

Видатна українська вчена, теоретик і практик організації дошкільної освіти С. Русова на основі вивчення досвіду зарубіжних педагогів, зокрема вперше відкривши новації німецьких педагогів Й. Песталоцці, Ф. Фребеля, звернула увагу на напрям роботи з питань інтеграції в суспільстві і серед дітей, і серед дорослих. Згідно $з$ іiі переконанням усі діти без винятку, незалежно від соціального становища, стану здоров'я та рівня психофізичного розвитку обов'язково мають бути 
залучені до виховного процесу. Важливою умовою результативності виховання вчена розглядала те, що особливі діти не мають жити ізольовано, оскільки необхідно дати оптимально можливий розвиток усім приспаним здібностям і повернути збуджені сили на корисну діяльність. 3 огляду на це одним із провідних принципів виховання педагог вважала принцип індивідуалізації, оскільки “діти дуже одно від одного відрізняються, хоч і межи ними є багато спільного” [6, 103].

Термін “інклюзивна" або “включена” освіта в зарубіжному та вітчизняному науковому обігу означує процес навчання в загальноосвітніх закладах дітей $з$ порушеннями здоров'я та розвитку, i, як наслідок, з особливими освітніми потребами [8, 4]. За визначенням, українських учених Н. Софій та Н. Найди, “інклюзивна освіта - це система освітніх послуг, що грунтується на принципі забезпечення основного права дітей на освіту та права навчатися за місцем проживання, що передбачає навчання дитини $з$ особливими освітніми потребами, зокрема, дитини 3 особливостями психофізичного розвитку, в умовах загальноосвітнього закладу” [19].

Згідно з рішенням ЮНЕСКО інклюзивна освіта окреслена в якості динамічного підходу, позитивного кроку назустріч різноманітності й унікальності дітей. Зважаючи на це, відмінності дітей повинні розглядатися не як проблема, а як можливість розвитку процесу навчання, тому інклюзивна освіта трактується не тільки як організаційно-технічні зміни, а й фундаментальне переосмислення філософії сучасної освіти $[4,9]$.

Починаючи від прийняття в 1994 р. Саламанської декларації (Іспанія), в освітній системі прогресивних країн світу особливої цінності набула різноманітність та індивідуальність людської особистості, що визначає особливість освітніх потреб як форму індивідуального вияву людської природи. Означена ідея набула подальшого обговорення на Всесвітньому форумі 3 освіти в Дакарі (2000), де філософським підгрунтям виявилися не тільки освіта та виховання для всіх, а й прогрес і новітні цілі освітнього процесу для людей усіх рас, релігій i націй незалежно від стану здоров'я. 3 того часу концепція інклюзивної освіти набула розповсюдження в багатьох країнах світу, зокрема і в Україні $[10,16]$.

У той час як становлення інклюзивної освіти в Україні значною мірою базується на зарубіжному досвіді в цій галузі, як слушно зауважує П. Єгоров. Звісно, через різні соціоекономічні умови та відмінність освітніх традицій, неможливо і неефективно примітивно копіювати напрацювання інших країн, тому актуальним $є$ визначення свого шляху розвитку інклюзивного навчання. Очевидним $є$ те, що розвиток вітчизняної інклюзивної освіти неможливий без переосмислення та адаптації, за умови лише формального перенесення вдалих зарубіжних моделей освітньої інтеграції в процес навчання і виховання українських загальноосвітніх закладів. На думку дослідників, впровадження інклюзивної освіти повинно відбуватися 3 урахуванні місцевих особливостей та використанні місцевих ресурсів, а в іншому випадку такі дії будуть безрезультатними $[3,6]$.

Необхідно відзначити, що із 2009 р. українське законодавство активно приводиться у відповідність до міжнародних вимог, зокрема, Конвенції ООН про права інвалідів, в основу якої покладена не медична, а соціальна модель розуміння інвалідності. У зв'язку з цим, зокрема, в Законі про загальну середню освіту був вперше впроваджено термін “спеціальні та інклюзивні класи для навчання дітей з особливими освітніми потребами", а в Концепції розвитку інклюзивної освіти, прийнятій Міністерством освіти і науки 1 жовтня 2010 р. вжито визначення “діти 3 особливими освітніми потребами” $[9,12]$.

У Концепції розвитку інклюзивної освіти України інклюзивне навчання характеризується як система комплексних заходів, спрямованих на забезпечення рівного доступу до якісної освіти дітям з особливими освітніми потребами шляхом організації їх навчання у загальноосвітніх навчальних закладах на основі застосування особистісно орієнтованих методів навчання, 3 урахуванням індивідуальних особливостей навчально-пізнавальної діяльності [11].

Серед розділів програми виховання і навчання дітей від двох до семи років “Дитина” (2012) вперше передбачено окремий розділ “Діти 3 особливими освітніми потребами”. У ньому визначені освітні завдання, які педагоги покликані розв’язувати, працюючи 3 вихованцями цієї категорії, означені умови успішної педагогічної роботи, розкривається їі зміст та показники успішного розвитку малюків. Для батьків, діти яких потребують особливої уваги, сформульовано спеціальні поради [19, 164].

Важливо, що в програмі “Дитина" розкривається сутність готовності закладу дошкільної освіти до роботи 3 дитиною 3 особливими освітніми потребами. Насамперед серед показників готовності окреслюється психологічна готовність вихователя, а саме наявність у нього бажання допомогти особливій дитині та їі батькам. Водночас, необхідним 


\section{ПСИХОЛОГО-ПЕДАГОГІЧНІ ДОСЛДЖЕННЯ АКТУАЛЬНИХ ПРОБЛЕМ ВПРОВАДЖЕННЯ ДОШКІЛЬНОЇ ІНКЛЮЗИВНОЇ ОСВІТИ В УКРАЇНІ}

вважається опанування вихователем спеціальними знаннями, уміннями і навичками, що забезпечують створення оптимально сприятливих умов для розвитку та навчання вихованців із психофізичними порушеннями, їх активної участі в усіх видах діяльності, спілкування зі звичайними ровесниками $[17,165]$.

Авторитетний вчений у галузі спеціальної освіти в Україні В. Бондар визначає інклюзивне навчання як "процес і результат включення дітей з особливостями психофізичного розвитку та дітей, які не мають таких порушень, до навчання в одному класі загальноосвітньої школи" [5]. Дослідники М. Ворон і Ю. Кавун зазначають, що дошкільна інклюзивна освіта передбачає процес, в якому заклад намагається відповідати потребам усіх категорій дітей з особливими потребами, вносячи необхідні зміни до навчальної програми та ресурсів, щоб забезпечити рівність можливостей.

За твердженнями І. Білецької та Л. Білецької, дошкільна інклюзивна освіта також передбачає застосування особистісно орієнтованих підходів, методів навчання для кожної дитини, 3 урахуванням іï особливостей психофізичних порушень можливостей та здібностей.

Інклюзивна освіта дітей дошкільного віку Н. Мачинською трактується як спільна освіта дітей з особливими потребами та їх звичайними ровесниками, в якій реалізується методика індивідуального підходу із врахуванням їх інтелектуально-особистісного потенціалу. Інклюзивна освіта дітей дошкільного віку 3 особливостями розвитку спільно з їх однолітками передбачає спільне навчання різних дітей в одній групі, а не в спеціально виділеній групі закладів дошкільної освіти [13].

На думку О. Нижник, інклюзія у закладі дошкільної освіти є процесом збільшення участі кожної дитини в його соціальному житті, а також засіб зниження рівня ізоляції дітей в усіх навчально-виховних заходах. "Інклюзія сприяє реструктуризації культури ЗДО, його правил і внутрішніх норм, практик для повного прийняття усього різноманіття дітей, $з$ їх особистими особливостями і потребами - стверджує дослідник, - Вона безпосередньо торкається усіх дітей, а не тільки особливо уразливих категорій, таких як діти 3 обмеженими можливостями; орієнтована на вдосконалення ЗДО не лише для дітей, але і для працівників. Кожна дитина має право відвідувати ЗДО поруч зі своїм домом. Різноманіття і несхожість дітей один на одного характеризується не проблемою, а найважливішим ресурсом, який можна використати в освітньому процесі. Інклюзія - це наявність тісних, грунтовних на дружбі відносин між ЗДО та суспільством. Таким чином, інклюзія - це процес розвитку гранично доступної освіти для кожного в освітніх установах, формування навчальновиховних процесів з постановкою адекватних цілей усіх дітей, процес ліквідації різних бар'єрів для найбільшої підтримки кожного та максимального розкриття їх потенціалу. Інклюзія - створення в групі умов, які диктуються змістом і методами пізнавальної діяльності для повної включеності кожного; це здатність колективу або співтовариства брати на себе відповідальність і сприяти рішенню проблем, що виникають 3 особливостей початкових даних дітей” [16].

Авторами навчально-методичного посібника “Індекс інклюзії: дошкільний навчальний заклад” інклюзія розглядається як процес, спрямований на перетворення закладів дошкільної освіти на інституції з освітнім простором, який стимулює та підтримує як вихованців, так і членів педагогічного колективу. Також вона спрямовується на розвиток місцевих громад, які високо цінують і підтримують досягнення кожного без винятку членів суспільства $[9,10]$.

На думку А. Аніщук, організація інклюзивного навчання в закладах дошкільної освіти потребує створення спеціальних умов задля забезпечення ефективності корекційно-розвивальної та навчально-виховної роботи з дітьми з особливими потребами. На думку вченої, першочерговим завданням, який стоїть перед інклюзивними дошкільними закладами є розробка особистісно орієнтованих педагогічних методів. Ці методи мають забезпечити успішну пізнавальну діяльність усіх вихованців, у тому числі й дітей 3 порушеннями психофізичного розвитку. Відповідно, результативність освітнього процесу значною мірою визначається тим, наскільки враховуються та реалізуються потенційні можливості навчання й розвитку кожної дитини, іiі індивідуальні особливості. Якими б не були фізичні чи психічні обмеження, у дитини завжди $\epsilon$ резерви для розвитку, використання яких може суттєво поліпшити якість їі життя [2, 66-67].

Сучасні дослідження (I. Гудим, I. Кузава, I. Свиридюк, Л. Сековець) показали, що навчання в інклюзивних групах допомагає дошкільникам інтегруватися в соціальне довкілля, запобігає виникненню почуття ізольованості, відчуження, формує почуття відповідальності за товаришів. На думку вчених, специфіка підготовки дітей старшого дошкільного віку із зоровим відхиленням у закладах дошкільної освіти передусім полягає в забезпеченні належних умов для розвитку дітей, 


\section{ПСИХОЛОГО-ПЕДАГОГІЧНІ ДОСЛДЖЕННЯ АКТУАЛЬНИХ ПРОБЛЕМ ВПРОВАДЖЕННЯ ДОШКІЛЬНОЇ ІНКЛЮЗИВНОЇОСВІТИ В УКРАЇНІ}

враховуючи їхні індивідуальні особливості, ступінь і характер зорового відхилення $[12,5]$.

У науковій праці В. Вертугіної розкрито педагогічні умови перебування дітей із зоровим відхиленням в групах дітей загального розвитку, зокрема: "забезпечення індивідуально-диференційованого навчання дітей старшого дошкільного віку із зоровим відхиленням; занурення дітей старшого дошкільного віку із зоровим відхиленням в активну пізнавально-ігрову діяльність; взаємодія дошкільного навчального закладу і сім’ї у підготовці дітей старшого дошкільного віку із зоровим відхиленням до навчання в школі”. Відповідно до окреслених педагогічних умов і принципів вченою розроблено модель підготовки дітей старшого дошкільного віку із зоровим відхиленням до навчання у школі $[6,103]$.

Наголошуючи на необхідності психологопедагогічного супроводу дітей із психофізичними порушеннями в інклюзивних закладах освіти, такі авторитетні фахівці як В. Бондар, А. Колупаєва, Н. Стадненко зауважують, що фізичне включення дітей, що потребують корекції психофізичного розвитку, в середовище здорових однолітків без спеціального супроводу є стихійною інтеграцією. Водночас, на думку М. Матвєєвої, С. Миронової, I. Садової, М. Сварник та ін. нездатність педагогів організувати освітній процес 3 урахуванням індивідуальних потреб може призвести як до соціальної ізоляції вихованця у ньому навіть в умовах інклюзії, і як результат ускладнення проблем його психофізичного розвитку $[7 ; 18]$.

Аналізуючи особливості психологопедагогічного супроводу дітей з особливими освітніми потребами в умовах інклюзивного освітнього закладу, Н. Андрійчук наголошує, що провідним напрямом цього процесу є психологічна діагностика дітей, надання психологічної підтримки педагогам та психологічної допомоги батьків. Психологічна діагностика дітей повинна відбуватися на різних етапах їх розвитку, зокрема, первинна діагностика, яка проводиться на етапі вступу дитини до освітнього закладу має на меті вивчення сильних і слабких сторін розвитку особистості. Проведення діагностичних мінімумів на різних етапах навчання дитини 3 порушеннями психофізичного розвитку передбачає вивчення динаміки її розвитку та подолання можливих труднощів під час кризових періодів [1].

В. Мушинський акцентує на тому, що психолого-педагогічний супровід дитини 3 особливими освітніми потребами повинен відбуватися відповідно до чітко розробленого плану, який складається 3 підготовчого, орієнтовного етапів, а також етапів уточнення проблеми, планування та реалізації індивідуальної програми i, закономірно, підсумкового. Усі зазначені етапи планування індивідуальної роботи дитини з порушеннями психофізичного розвитку $\epsilon$ вирішальним для отримання позитивного результату [15].

Водночас дослідники А. Шеффер і Ж. Романчак зауважують, що передусім необхідно зосередитися на етапі реалізації індивідуальної програми, оскільки саме на цьому етапі, “ознайомившись із особливостями психофізичного розвитку дитини, розробивши перед тим індивідуальний план та узгодивши його 3 усіма спеціалістами, психолог аналізує, перш за все, відповідність інструментарію (стимулів), вибрані методики та встановлює ступінь їх позитивної дії для реалізації свої цілей. Саме на цьому етапі психолог веде ретельну роботу 3 педагогами, батьками та оточуючим дитину середовищем, прилаштовує інструментарій до можливостей дитини, враховуючи тип порушень" [20].

У методичному посібнику "Психологічний супровід інклюзивної освіти" авторського колективу під керівництвом А. Обухівської акцентується, що освіта дітей з психофізичними порушеннями передбачає включення їх у спільну діяльність разом з іншими дітьми, починаючи 3 дошкільного віку. Проблеми організації психологопедагогічного супроводу дітей $з$ особливими освітніми потребами, на думку авторів, має розглядатися з точки зору психологічних, педагогічних, організаційно-методичних вимог щодо організації процесу інклюзивного навчання. Результати досліджень свідчать, що робота 3 дітьми 3 особливими освітніми потребами має бути спрямована на організацію цілеспрямованої підтримки через надання психологічної, соціальної допомоги всіх учасників навчально-виховного процесу [16, 14].

Важливим напрямом теорії і практики впровадження інклюзивної освіти в Україні стало дослідження змісту і завдань психологопедагогічного супроводу дитини 3 особливими освітніми потребами в умовах інклюзивних груп закладів дошкільної освіти. Метою цієї систематичної комплексної діяльності команди фахівців та батьків дитини визнано створення оптимальних умов особистісного розвитку вихованця, опануванню ним знаннями, уміннями і навичками, успішній адаптації, реабілітації, самореалізації та інтеграції в соціум.

Психолого-педагогічний супровід дітей 3 особливими освітніми потребами в умовах 


\section{ПСИХОЛОГО-ПЕДАГОГГЧНІ ДОСЛДЖЕННЯ АКТУАЛЬНИХ ПРОБЛЕМ ВПРОВАДЖЕННЯ ДОШКІЛЬНОЇ ІНКЛЮЗИВНОЇ ОСВІТИ В УКРАЇНІ}

інклюзивного навчання в системі освіти визначається пріоритетним напрямом діяльності всіх учасників освітнього процесу. У практиці загального закладу завдання психологопедагогічного супроводу здійснює спеціально організована команда фахівців, взаємодія яких $\epsilon$ важливою умовою успішності розв' язання завдань інклюзивної освіти. Це передбачає залучення різнопрофільних фахівців, необхідних для розробки стратегії навчання дитини з особливими освітніми потребами в умовах інклюзії. До складу команди фахівців входять вчитель, асистент вчителя, практичний психолог, соціальний педагог, учительдефектолог (учитель-логопед), керівник освітнього закладу. В такому складі має функціонувати команда фахівців індивідуального супроводу кожної дитини з особливими потребами в загальноосвітньому навчальному закладі [14].

Результати психолого-педагогічних досліджень свідчать, що найсприятливішим віковим періодом для впровадження інклюзивної освіти є дошкільне дитинство, оскільки в дітей цього віку немає жодних упереджень стосовно своїх однолітків, які потребують корекції психофізичного розвитку, що дозволяє їм легко налагоджувати контакти з ними. На думку дослідників, період дошкільного дитинства також є сприятливим для інтеграції дітей означеної категорії, що пов'язується із здатністю дошкільників спокійніше прийняти однолітка $з$ вадами психофізичного розвитку, менше акцентувати увагу на його дефекті, а можливо і взагалі його не помічати [7, 57].

Таким чином, впровадження дошкільної інклюзивної освіти на сучасному етапі реформування системи спеціальної допомоги дітям із особливими освітніми потребами в Україні активізували психолого-педагогічні дослідження цієї проблеми з метою оптимізації цього процесу на практиці. У сучасних теоретичних i практичних дослідженнях інклюзивна освіта визначається як: ознака приналежності до цивілізованого, демократичного суспільства; доступ до якісної освіти дітей з особливими освітніми потребами; спосіб налагодження комунікації осіб з порушеннями психофізичного розвитку з однолітками та дорослими, а таким чином і гармонізація відносин в українському суспільстві; важливий напрям розвитку держави в галузі соціальної політики; засіб соціальної адаптації та інтеграції осіб з порушеннями психофізичного розвитку в суспільні процеси; система освітніх послуг, спрямована на задоволення пізнавальних потреб, розширення сфери пізнавальних інтересів тощо.

Дошкільна інклюзивна освіта передусім розглядається в якості спеціально організований процес, в якому заклад намагається задовільнити потреби всіх дітей, вносячи необхідні зміни як до навчальної програми, так і технічних умов та психолого-педагогічного супроводу вихованців 3 метою забезпечення рівності можливостей. Дошкільній інклюзивній освіті дослідниками правомірно відводиться пріоритетне значення у формування свідомого ставлення до людей із особливостями психофізичного розвитку як рівноправних членів суспільства, оскільки в дітей дошкільного віку немає жодних упереджень стосовно своїх однолітків, які потребують корекції психофізичного розвитку, що дозволяє їм менше акцентувати увагу на вади психофізичного розвитку, а можливо і взагалі його не помічати, завдяки чому легко налагоджувати контакти 3 ними.

\section{ЛІТЕРАТУРА}

1. Андрійчук Н. М. Психолого-педагогічний супровід дітей з вадами зору в умовах інклюзивної освіти. URL: http://eprints.zu.edu.ua/16389/1/.pdf.

2. Аніщук А. М. Інклюзивна освіта: навчальний посібник для студентів вищих навчальних закладів спеціальності “Дошкільна освіта” . Ніжин: НДУ ім. М. Гоголя, 2016. 227 с.

3. Ашиток Н. Проблеми інклюзивної освіти в Україні. Людинознавчі студіі. Серія “Педагогіка”. Випуск 1/33 (2015). С. 4-11.

4. Болотов В.А., Сериков В. В. Компетентностная модель: от идеи к образовательной программе. Педагогика. 2003. № 10. С. 8-14.

5. Бондар B.I. Інклюзивне навчання та підготовка педагогічних кадрів для його реалізації. Науковий часопис НПУ імені М. П. Драгоманова. Серія 19. Корекиійна педагогіка та психологія. Зб. Науковихпращь. Київ:НПУ іменіМ.П.Драгоманова, 2010. № 15. С. 39-43.

6. Вертугіна В. М. Інклюзивна освіта дітей дошкільного віку. “Молодий вчений”. № 3.2 (43.2), березень, 2017 р. С. 102-105.

7. Завальнюк О. О. Дошкільна інклюзивна освіта як шлях максимальної соціалізації дітей 3 вадами психофізичного розвитку. URL: file://C:/ Users/admin/Downloads/Znpkhist_2009_1_15.pdf.

8. Заєркова Н. В. Інклюзивна освіта від А до Я: порадник для педагогів і батьків / Н. В. Заєркова, А. О. Трейтяк. Київ. 2016. 68 с.

9. Індекс інклюзії: дошкільний навчальний заклад: Навчально методичний посібник/Кол. упорядників: Патрикеєва О. О., Дятленко Н. М., Софій Н. 3., Найда Ю. М. Під заг. ред. Шинкаренко В. І. Київ: ТОВ “Видавничий дім “Плеяди”, 2011. 100 с.

10. Качмар О. Сучасні тенденції розвитку 


\section{ПСИХОЛОГО-ПЕДАГОГІЧНІ ДОСЛДЖЕННЯ АКТУАЛЬНИХ ПРОБЛЕМ ВПРОВАДЖЕННЯ ДОШКІЛЬНОӤ ІНКЛЮЗИВНОЇ ОСВІТИ В УКРАЇНІ}

інклюзивної освіти в Україні (досвід ІваноФранківської області). Соціальне партнерство в інклюзивній освіті: європейський вектор, українські реалії. Збірник наукових праџь за матеріалами Міжнародної науковопрактичної конферениії (15 березня 2018 р.). Ізмаїл: РВВ ІДГУ, 2018. 72 с. С. 15-19.

11. Концепція розвитку інклюзивної освіти: наказ Міністерства освіти і науки України від 01.10.2010 p. № 912. URL: https://mon.gov.ua/ua/ $\mathrm{npa} /$ prozatverdzhennya-kontseptsii-rozvitkuinklyuzivnogo-navchannya.

12. Кузава І. Б. Інклюзивна освіта дошкільників, які потребують корекції психофізичного розвитку: теорія і методика. Луцьк: ПП Іванюк В. П., 2013. 292 c.

13. Мачинська Н. Професійна підготовка вчителя в умовах сучасної освіти. Педагогіка, психологія професійної освіти. 2007. № 6. С. 1623.

14. Мушинський В. П. Психолого-педагогічний супровід інклюзивного навчання в початковій школі. URL: http://osvita-dnepr.com/index.php/ metodichni-rekomendatsiji/1492-psikhologopedagogichnijsuprovid-inklyuzivnogo-navchannya-vpochatkovij-shkoli.

15. Нижник О. М. Допомога дітям з особливими потребами: Психолог. Бібліотека. Київ: Главник, 2004. 206 c.

16. Психологічний супровід інклюзивної освіти: метод. рек. / автор. кол. за заг. ред. А. Г. Обухівська. Київ: УНМЦ практичної психології і соціальної роботи, $2017.92 \mathrm{c}$.

17. Проскура О. В., Кочина Л. П., Кузьменко В. У., Кудикіна Н. В. Дитина: програма виховання і навчання дітей від 2 до 7 років/ наук. кер. О.В.Проскура. Київ: Київ. ун-т ім. Б. Грінченка, 2012. 492 с.

18. Садова І., Колупаєва А. А., Найда Ю. М. Інклюзивна освіта для дітей з особливими освітніми потребами в умовах сучасної початкової школи. Молодь і ринок, №8 (151), 2017. С. 106-111.

19. Софій Н. 3. Концептуальні аспекти інклюзивної освіти. Інклюзивна школа: особливості організації та управління: навч.метод. посіб. Київ. 2007. 128 с.

20. Шеффер А. П., Романчак Ж. І. Психологопедагогічний супровід дітей $з$ особливими освітніми потребами в умовах інклюзивного навчання. URL: https://www.google.com.ua/ urlsat\&uct j\&q $=\&$ esc $=$ s\&source-web\&cd $=2 \&$ ved $=0 \mathrm{CDMQFj}$.

\section{REFERENCES}

1. Andriichuk, N. M. Psykholoho-pedahohichnyi suprovid ditei z vadamy zoru v umovakh inkliuzyvnoi osvity [Psychological and pedagogical support of children with visual impairments in an inclusive education]. Available at: http://eprints.zu.edu.ua/ 16389/1/.pdf. [in Ukrainian].

2. Anishchuk, A. M. (2016). Inkliuzyvna osvita: navchalnyi posibnyk dlia studentiv vyshchykh navchalnykh zakladiv spetsialnosti "Doshkilna osvitao [Inclusive education: a textbook for students of higher education institutions in the specialty "Preschool educationo]. Nizhyn, 227 p. [in Ukrainian].

3.Ashytok, N. (2015). Problemy inkliuzyvnoi osvity $\mathrm{v}$ Ukraini [Problems of inclusive education in Ukraine]. Anthropological studies. no. 1/33. pp. 4 11.[in Ukrainian]

4. Bolotov, V. A. \& Serikov, V. V. (2003). Kompetentnostnaya model: ot idei k obrazovatelnoy programme [Competence model: from idea to educational program]. Pedagogy.No.10, pp. 8-14. [in Ukrainian].

5. Bondar, V.I. (2010). Inkliuzyvne navchannia ta pidhotovka pedahohichnykh kadriv dlia yoho realizatsii [Inclusive education and training of pedagogical staff for its implementation]. Scientific journal of NPU named after M. P. Drahomanov. Series 19. Correctional pedagogy and psychology. Coll. of scientific works. Kyiv. No.15, pp. 39-43. [in Ukrainian].

6. Vertuhina, V.M. (2017). Inkliuzyvna osvita ditei doshkilnoho viku [Inclusive education of preschool children]. "Young scientist”. No. № 3.2 (43.2), pp.102-105. [in Ukrainian].

7. Zavalniuk, O.O. Doshkilna inkliuzyvna osvita yak shliakh maksymalnoi sotsializatsii ditei z vadamy psykhofizychnoho rozvytku [Preschool inclusive education as a way of maximum socialization of children with mental and physical disabilities]. Available at: file://C:/Users/admin/Downloads/ Znpkhist_2009_1_15.pdf. [in Ukrainian].

8. Zaierkova, N. V. (2016). Inkliuzyvna osvita vid A do Ya: poradnyk dlia pedahohiv $i$ batkiv [Inclusive education from A to Z: a guide for teachers and parents]. Kyiv, 68 p. [in Ukrainian].

9. Indeks inkliuzii: doshkilnyi navchalnyi zaklad: Navchalno metodychnyi posibnyk [Inclusion index: preschool educational institution: Educational methodical manual]. Team of compilers: Patrikeeva O. O., Dyatlenko N. M., Sofiy N. Z., Naida Yu. M. Edited by Shinkarenko V. I. Kyiv, 100 p. [in Ukrainian].

10. Kachmar, O. (2018). Suchasni tendentsii rozvytku inkliuzyvnoi osvity v ukraini (dosvid ivanofrankivskoi oblasti) [Modern tendencies of development of inclusive education in Ukraine (experience of Ivano-Frankivsk region)]. Social partnership in inclusive education: European vector, Ukrainian realities. Collection of scientific 
works on the materials of the International scientific and practical conference. Izmail, pp. 1519. [in Ukrainian].

11. Kontseptsiia rozvytku inkliuzyvnoi osvity: nakaz Ministerstva osvity i nauky Ukrainy vid 01.10.2010 r. № 912. [The concept of development of inclusive education: the order of the Ministry of Education and Science of Ukraine from 01.10.2010. № 912.]. Available at: https://mon.gov.ua/ua/npa/ prozatverdzhennya-kontseptsii-rozvitkuinklyuzivnogo-navchannya. [in Ukrainian].

12. Kuzava, I. B. (2013). Inkliuzyvna osvita doshkilnykiv, yaki potrebuiut korektsii psykhofizychnoho rozvytku: teoriia i metodyka [Inclusive education of preschoolers which need the correction of psychophysical development: theory and methods]. Lutsk, 292 p. [in Ukrainian].

13. Machynska, N. (2007). Profesiina pidhotovka vchytelia v um ovakh suchasnoi osvity [Teacher professional training in modern education]. Pedagogy, psychology of vocational education. No.6. pp. 16-23. [in Ukrainian].

14. Mushynskyi, V. P. Psykholoho-pedahohichnyi suprovid inkliuzyvnoho navchannia $v$ pochatkovii shkoli [Psychological and pedagogical support of inclusive education in primary school]. [Elektronnyi resurs]. Available at: http://osvita-dnepr.com/ index.php/metodichni-rekomendatsiji/1492psikhologo-pedagogichnijsuprovid-inklyuzivnogonavchannya-v-pochatkovij-shkoli. [in Ukrainian].

15. Nyzhnyk, O. M. (2004). Dopomoha ditiam z osoblyvymy potrebamy [Help for children with special needs]. Kyiv, 206 p. [in Ukrainian].

16. Psykholohichnyi suprovid inkliuzyvnoi osvity: metod. rek [Psychological support of inclusive education: meth. rec. (2017). Author. team for gen. ed. A.G. Obukhovskaya. Kyiv, 92 p. [in Ukrainian].

17. Proskura, O. V., Kochina, L. P., Kuzmenko, V. V. \& Kudykina, N. V. (2012). Dytyna: prohrama vykhovannia i navchannia ditei vid 2 do 7 rokiv [Child: the program of education and training of children from 2 to 7 years]. Kyiv, $492 \mathrm{p}$. [in Ukrainian].

18. Sadova, I., Kolupaieva, A. A. \& Naida, Yu. M. (2017). Inkliuzyvna osvita dlia ditei z osoblyvymy osvitnimy potrebamy v umovakh suchasnoi pochatkovoi shkoly [Inclusive education for children with special education needs in a modern primary school]. Youth and the market, No.8 (151), pp. 106-111. [in Ukrainian].

19. Sofii, N. Z. (2007). Kontseptualni aspekty inkliuzyvnoi osvity [Conceptual aspects of inclusive education]. Inclusive school: features of organization and management: educational manual. Kyiv, 128 p. [in Ukrainian].

20. Sheffer, A. P. \& Romanchak, Zh. I. Psykholoho-pedahohichnyi suprovid ditei $z$ osoblyvymy osvitnimy potrebamy $v$ umovakh inkliuzyvnoho navchannia [Psychological and pedagogical support of children with special educational needs in the conditions of inclusive education]. Available at: :https://www.google.com.ua/

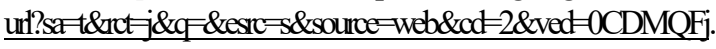
[in Ukrainian].

Стаття надійшла до редакції 09.06.2020

\section{G58080ल2058080}

“Учитель готується до гарного уроқу все життя... ТТақа духовна і білософська основа нашого фаху і технологія нашої пращі".

Василь Сухомлинський
уқраїнсьжий педагог

“У ^юдини є три щляхи, щоб чинити розумно: найблагородніший - роздум, найлегший-наслідування, найгіркіший-досвід”.

Конфучиiй

давньокитайсьжий ббілособ

“Виховання - справа важка, і поліпшення його умов - одна з священних обов'язқів қожної людини, бо немає нічого важливішого, якосвіта самого себе і свойх ближніх".

Соқрат

давньогреиький білософ

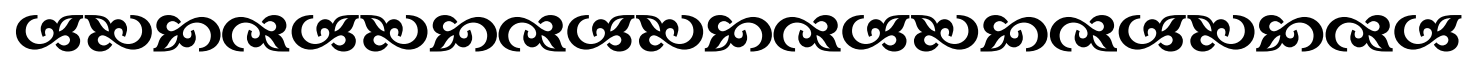

